\title{
Tectonic structure of the convergent Pacific margin offshore Costa Rica from multichannel seismic reflection data
}

\author{
K. Hinz \\ Bundesanstalt für Geowissenschaften and Rohstoffe, Hannover, Germany \\ R. von Huene and C.R. Ranero \\ GEOMAR, Research Center for Marine Geosciences, Kiel, Germany
}

\section{PACOMAR Working Group ${ }^{1}$}

\begin{abstract}
The Middle America Trench between the Cocos Ridge and a well-studied corridor off the Nicoya Peninsula has a more varied morphology and structure than previously reported. The morphological positive features on the lower plate significantly affect the upper plate structure. The Cocos Ridge has uplifted the margin opposite the Osa Peninsula. Northwest of Cocos Ridge, numerous seamounts on the oceanic crust sculptured the margin as they subducted. A seamount and a huge slump in the trench axis that currently block lateral sediment transport affect the sediment currently accreted and subducted. The greater portion of the trench sediment is subducted beneath a lower slope accretionary mass. Beneath the middle and upper slope is a margin wedge consisting of a high-velocity rock with few internal reflections. Its upper surface has a nondirectional random relief commonly $500 \mathrm{~m}$ high in the middle slope area. Overlying this surface is a low-velocity cover of slope sediment which shows little transgressive stratigraphy and can be traced landward into an inferred Eocene section beneath the shelf. The shelf basement is composed of Nicoya complex (ophiolite) with the same acoustic velocity, similar structure, and no apparent dividing geologic boundary with the margin wedge. We favor a seaward continuation of the Nicoya complex to the middle slope and emphasize the evidence for a non-steady state Tertiary tectonic history.
\end{abstract}

\section{Introduction}

The Pacific margin of Costa Rica contains the boundary between the Caribbean and Cocos Plates that is marked by the Middle America Trench. During the 1970s, the trench was best known off Guatemala where the classical work of Seely et al. [1974] was commonly used as a model to help interpret less clear data along other accretionary margins. After two legs of Deep Sea Drilling Project (DSDP) drilling off Guatemala and the discovery that the majority of that margin consisted of a Cretaceous ophiolite [von Huene et al., 1985], emphasis shifted to the area off Nicoya Peninsula. Here an early seismic record had imaged the top of the subducting plate from the trench axis

\footnotetext{
${ }^{1}$ E. Flueh, D. Klaeschen, J. Leinbach, O. Ruoff, H.O. Bargeloh, M. Block, J. Fritsch, P. Kewitsch, H. Meyer, B. Schreckenberger, and J. Mrazek.
}

Copyright 1996 by the American Geophysical Union.

Paper number $95 \mathrm{TC} 02355$.

0278-7407/96/95TC-02355\$10.00 landward over $50 \mathrm{~km}$ to the coast [Buffler, 1982]. The structural simplicity of the seismic image made the area attractive for further study. A corridor was investigated with swath mapping and high-resolution seismic work, which showed a relatively simple morphology [Shipley and Moore, 1986; Moore and Shipley, 1988]. That swath mapping was followed by the first three-dimensional (3-D) seismic study in a trench area (Figure 1) [Shipley et al., 1990, 1992; Stoffa et al., 1991]. The authors of these studies interpreted the 3-D seismic data as showing a large accretionary wedge composed of trench sediment extending to the coast line consistent with a steady state accretion model [Seely et al., 1974]. An earlier interpretation that much of the margin consists of ophiolite like the Guatemalan margin implies a variable tectonic history [von Huene et al., 1985]. The difference between these two tectonic histories has not been resolved.

During 1991 and 1992, the German research vessel Sonne made two cruises (SO-76 and -81) that greatly expanded swath mapping, seismic reflection, and refraction coverage from the 3D study area off Nicoya Peninsula for approximately $250 \mathrm{~km}$ to the southeast where the crest of Cocos Ridge is subducted (Figure 1). The results from Sonne SO-76 showed a seafloor morphology far more complex than that in the 3-D area [von Huene et al., 1995]. That pattern explains the local complexity indicated in earlier seismic records [Crowe and Buffler, 1985]. On the basis of monitor and records processed onboard, a shipboard interpretation of seismic records was made in the cruise report of SO-81 [Hinz et al., 1992]. An analysis of gravity data, highresolution transducer acoustic profiles, and sampling was also included in the cruise report. In this paper we concentrate on the interpretation of the seismic reflection data from SO-81 processed after the cruise.

\section{Previous Studies and Tectonic Setting}

The bathymetry of the Pacific side of Costa Rica, mapped early in the post World War II voyages of oceanographic vessels along the Pacific Coast [Fisher, 1961], showed numerous seamounts fringing the northern flank of the Cocos Ridge. The improved mid-1970s bathymetry showed a separate seamountcovered province. The subducting Cocos Ridge opposite the Osa Peninsula was clearly portrayed. Swath mapping of the Pacific convergent margin shows three morphologic domains on the oceanic plate (Figure 1), each with a distinct relief. When that relief is subducted, it affects the upper plate at a scale that can be seen in high-resolution seafloor mapping. Across the trench axis 


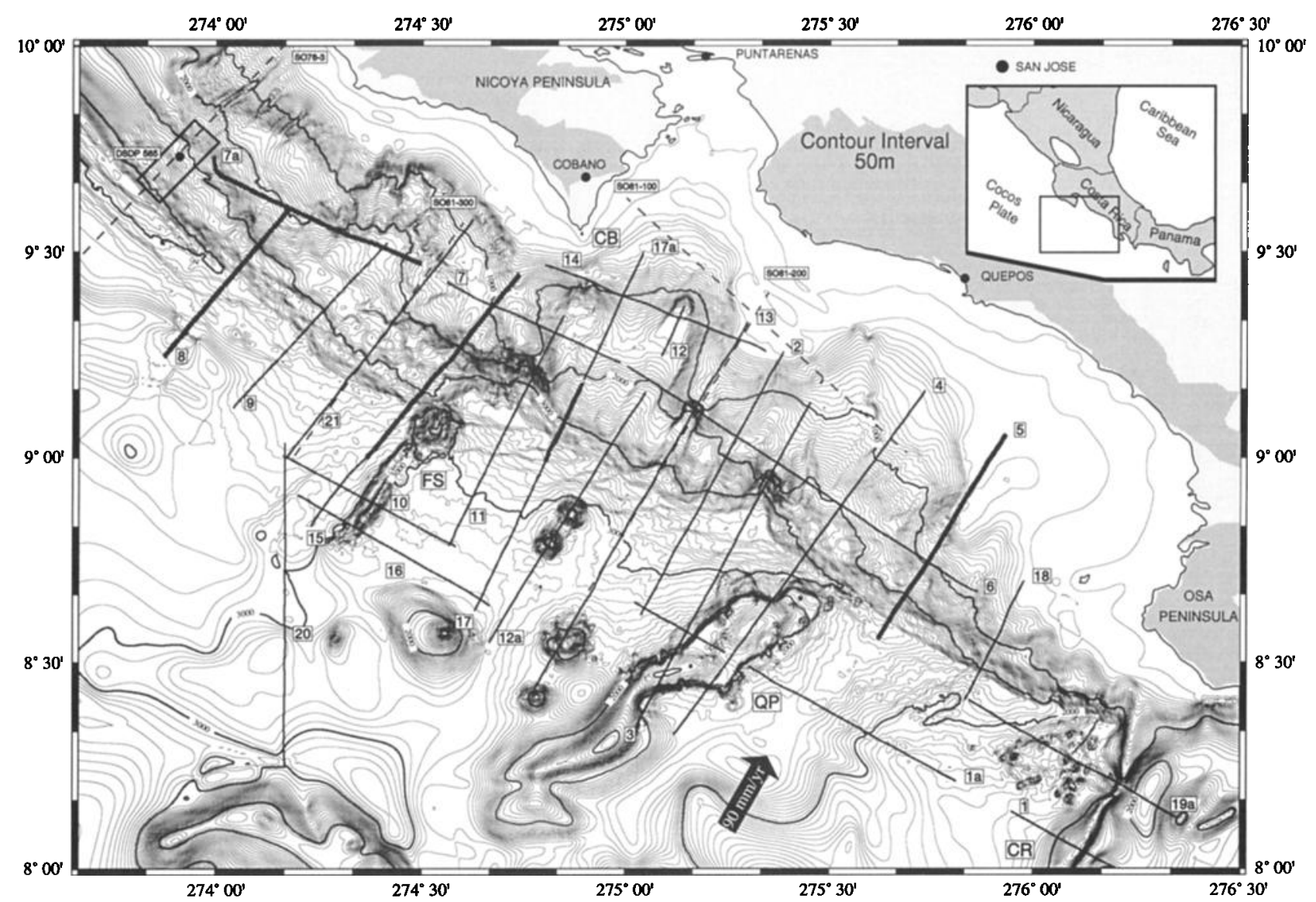

Figure 1. Location of seismic reflection and refraction lines on the bathymetric swath map offshore Costa Rica [after von Huene et al., 1995]. Seismic reflection lines are continuous lines; the bold segments are locations shown in figures. Seismic refraction data are plotted as dashed lines (after Ye et al. (submitted manuscript, 1995)). FS is Fisher Seamount, QP is Quepos Plateau, CB is Cabo Blanco, and CR is Cocos Ridge. The locations of the 3-D data analyzed by Shipley et al. [1992] and the Deep Sea Drilling Project (DSDP) hole 565 are also shown. The heavy shading shows the onshore extent of the ophiolite outcrops (peridotite, basalt, and deep water sedimentary rock, [US. Geological Survey ,1987]).

the morphology of the lower and middle continental slope reflects the smooth or rough character observed on the oceanic lower plate [von Huene et al., 1995]. Northwest of the Fisher Seamount, the smooth Pacific basin seafloor facing the Nicoya Peninsula is similar to the less rugged continental slope morphology. Opposite the ocean floor covered with seamounts, the continental slope is indented and has a more rugged morphology. The Cocos Ridge subducts beneath a constricted continental slope that rises steeply up to a shelf distinguished by the uplifted Osa Peninsula. The apparent correspondence of morphotectonic features across the trench axis suggests a tectonic effect on the upper plate from the morphology of the subducting plate. A tectonic history [Lonsdale and Klitgord, 1978] indicates that this plate configuration has existed for at least the past million years. During this time, the Cocos Ridge migrated little from its present position, but the boundary of the seamount domain may have migrated from the middle of Nicoya Peninsula to its southeast end. The first-order morphotectonic features seen in swath mapping of the ocean basin indicate that the topography subducting beneath the margin during the past million years of tectonism has significantly affected its structure.
The interpretation of seismic records off the Nicoya Peninsula is debated despite a nearly 20-year history of seismic studies there. A record acquired by EXON during their 1971 exploration offshore Guatemala was considered a standard image of convergent margin accretion [Seely et al., 1974]. The EXON record was of much better quality than the data obtained onboard academic vessels, and many workers interpreted the Costa Rican seismic data in accord with the Guatemalan model. Drilling of the Guatemalan margin on Leg 84 penetrated the slope deposits to a ubiquitous basement reflector. When multiple penetrations recovered ophiolitic rock, the Guatemala margin was interpreted as being composed largely of accreted ophiolite rather than accreted trench sediment. The site drilled off Costa Rica was interpreted in accord with those Guatemalan drilling results by the Leg 84 shipboard party [von Huene et al., 1985]. A true test of this interpretation, however, was not achieved by drilling off Costa Rica since the slope deposits were not completely penetrated.

Most early seismic records showed a unit with a very reflective rough surface (this term is retained here because of previous use and is described more fully in the following text) 
below the slope sediment that scattered the seismic energy. No reliable intemal reflections were apparent beneath the surface, especially in unmigrated records. The lack of resolution was subsequently overcome by acquiring the first academic 3-D survey [Stoffa et al., 1991]. A highly variable structure from line to line was indicated in the 3-D images, and a group of landward dipping reflections on the lower slope was interpreted as structures in an accreted pile of trench sediment. These structures were inferred to extend to the coast because of the rough surface reflection [Shipley et al., 1992].

During SO-76, an onshore/offshore wide-angle seismic experiment was conducted (Figure 1) through the 3-D area off Nicoya Peninsula [Flueh et al., 1992; von Huene and Flueh, 1994]. These data were interpreted with ray-tracing techniques using the structural image of a reflection profile through the 3-D area [Shipley et al., 1992] and forward modeling of the wideangle data. The velocity structure from the profile is well constrained in the upper slope from about $20 \mathrm{~km}$ landward of the trench axis to the coast. The unit characterized by an irregular and reflective rough surface beneath slope sediment corresponds to a sudden velocity increase from about 2.0 to $4.6 \mathrm{~km} / \mathrm{s}$. This velocity boundary is most pronounced in the middle slope, and the contrast decreases toward the trench axis. Across the lower slope the velocity within the unit below the rough surface decreases from 4.5 to $2.0-3.5 \mathrm{~km} / \mathrm{s}$ (S. Ye et al., Crustal structure of subduction zone off Costa Rica derived from OBS refraction and wide-angle reflection seismic data, submitted to Tectonics, 1995; hereinafter referred to as Ye et al., submitted manuscript, 1995). A similar velocity structure was observed with ocean bottom seismometer (OBS) instruments across the Guatemala slope [Ambos and Hussong, 1985]. In addition, no boundary was found off Costa Rica that might indicate the buttress against which trench sediment has been accreted. Therefore the interpretation of massive sediment accretion or massive ophiolite off Costa Rica is still debatable.

The shipboard interpretation of Hinz et al. [1992] invokes a boundary near the middle slope between a wedge of highvelocity nonreflective rock and a frontal accretionary prism. Accretion has uplifted the front of the wedge to form a landward dipping buttress against which trench sediment has accreted [Hinz et al., 1992]. Beneath the wedge, some sediment is probably underplated, and subducting sediment is commonly imaged to the landward extent of the lines. The upper surface of the high-velocity wedge is the ubiquitous rough surface noted in most seismic records off Costa Rica.

Both contractile and extensional structures with relatively small displacements [Mclntosh et al., 1993] are displayed. Interpretation based on extending the reflective rough surface upslope from the frontal accretionary complex infers an upper slope body comprised largely of consolidated pre-Eocene accreted trench sediment. The alternate interpretations, based on extending the Nicoya ophiolites downslope, infer a margin wedge composed of ophiolite with only a small prism of accreted trench sediment. The two models differ in the position of the contact between ophiolite and accreted trench sediment. The former would have this contact in a data gap along the coast and the latter within about $20 \mathrm{~km}$ of the trench axis. The arguments are summarized in greater detail elsewhere [von Huene and Flueh, 1994], and, clearly, the existing geophysical and other data are insufficient to reject either of the two debated positions.

\section{Data Acquisition and Processing}

During SO-81, $1859 \mathrm{~km}$ of multichannel seismic reflection data were acquired by the Bundesanstalt für Geowissenschaften und Rohstoffe (BGR) instrument system. The seismic energy was generated by two 19.5 -m-long linear arrays consisting each of 10 air guns. The array was tuned to a signal bubble ratio $12: 1$. Total volume was $51.2 \mathrm{~L}$ (3124 cubic inches) operating at a $13.5-\mathrm{MPa}$ pressure (135 bar, $1920 \mathrm{psi}$ ), towed at 7-m depth. The energy source was fired every $50 \mathrm{~m}(18 \mathrm{~s})$. The seismic signal was received through an AMG 37-43 analog streamer. Each 50-mlong active channel consisted of three hydrophone groups with 16 hydrophones per group. A Texas Instruments DFS V with 48 channels recorded data at a 4 -ms sampling rate, with a constant 24-dB gain and a 5.3- to 64-Hz band-pass filter. The Global Positioning System was the primary navigation system.

Records from three areas of different water depth and geology across the margin presented different problems for processing of seismic reflection data and required different processing strategies:

1. The water-layer multiple across the shelf and upper slope area was attenuated through frequency/wavenumber $(\mathrm{F} / \mathrm{K})$ filtering in the common midpoint (CMP) gather domain and a near-trace mute.

2. The water-layer multiple from areas of the steep slope was attenuated with a different procedure. The strong dip of the slope causes the energy of the seafloor multiple to occur as nearly flat arrival in the CMP gathers. However, it occurs as linear steeply dipping arrivals in the shot gathers, which in most cases are spatially aliased. After a dynamic correction to avoid the aliasing, the water-layer multiple was attenuated in the shot gather domain through $\mathrm{F} / \mathrm{K}$ filtering and gentle trace mixing in order to remove any possible remainder of the spatially aliased noise.

3. In the deep basin, the major problem is the scarcity and random distribution of reflections in the igneous basement. The processing velocities for the basement were obtained from the compilations of velocity depth profiles based on refraction experiments in oceanic crust [White et al., 1992; Mutter and Mutter, 1993].

Further processing includes prestack predictive deconvolution to attenuate reverbatory noise, compression of the wavelet and whitening of the frequency spectrum, and post-stack time migration. The processing sequence is shown in Figure 2.

\section{Description of the Seismic Images}

\section{The Ocean Crust}

Off Costa Rica, the ocean crust formed along two main centers of crustal generation [Lonsdale and Klitgord, 1978]. The igneous crust of the northwest part formed along the East Pacific Rise, whereas in the southeast the crust formed along the Cocos spreading center. The boundary between these crustal provinces is called the "rough-smooth" boundary [Hey, 1977]. Fisher Seamount and its southwest-trending ridge of volcanism (Figure 1) were extruded along the boundary [von Huene et al., 1995]. Where crossed by seismic lines, the boundary without volcanic intrusion is a sharp fault cutting both igneous and sedimentary sections [Buffler, 1982] with the northwest displaced down relative to the southeast province. Magnetic anomalies of the southeast provence include those of Cocos Ridge, which formed 
Processing sequence

1) Editing
2) Static correction
3) Velocity analysis

In areas of steep slope:

4) $\mathrm{F} / \mathrm{K}$ multiple attenuation in Shot Gathers.

5) Trace mixing in Shot Gathers.

6) Common Mid Point sorting

In the upper slope and continental shelf:

7) $\mathrm{F} / \mathrm{K}$ multiple attenuation in Common Mid Point Gathers

8) Near offset traces Mute

9) Predictive Deconvolution

Two Design Windows (based on geology)

First gate: about $2.5 \mathrm{~s}$ from seafloor

Second gate: 3 to $4 \mathrm{~s}$ long with

$0.5 \mathrm{~s}$ overlap with first window

Prediction Length:

First gate: $32 \mathrm{~ms}$

Second gate: $40 \mathrm{~ms}$

Operator Length:

$256 \mathrm{~ms}$

10) Normal Move Out correction.

11) Stretch Mute

12) Horizontal stacking $2400 \%$

13) Time migration

14) Band-pass filtering

At seafloor: $5 / 8-60 / 80 \mathrm{~Hz}$

At about 2 TWT beneath seafloor: $3 / 5-40 / 60$

$\mathrm{Hz}$

15) Amplitude normalization

Figure 2. The processing sequence.

at the Galapagos Hotspot and extends southwest of the Osa Peninsula.

The SO81 seismic images (Plate 1 and Figures 3-5) show a cover of sediment 450- to 600-ms (two-way travel time (TWTT)) thick over the generally smooth igneous basement topography between seamounts and ridges. The sediment cover is $450 \mathrm{~ms}$ thick in the northwest province and increases in the southeast to $600 \mathrm{~ms}$. It consists of a basal section $200-300 \mathrm{~ms}$ thick with good stratal continuity overlain by 250 - to 300 -ms-thick little stratified facies.

The top of the igneous oceanic crust is clearly delineated in the seismic images by a strong reflection. In the seismic records (Plates $1 \mathrm{~b}$ and $1 \mathrm{c}$ ), $15 \mathrm{~km}$ seaward of the trench axis, the topography of the igneous crust and seafloor is smooth except where disrupted by seamounts or the displacement across the Fisher Seamount ridge. However, within $15 \mathrm{~km}$ of the trench axis, normal faulting creates a "staircase" or a horst and graben structure that displaces the oceanic crust as it is flexed downward into the trench (Plate 1b). Displacement ranges from 50 to $150 \mathrm{~m}$, the large offset occurring on widely spaced faults and the smaller on more closely spaced ones. In the northwest province, the faults strike $15^{\circ}$ to the trench axis [Shipley and Moore, 1986], whereas in the southeast province they enter the trench at $30^{\circ}$ angle to the axial trend as observed in swath-map bathymetry (Figure 1). Where Cocos Ridge subducts, few normal faults are observed.

The base of the oceanic crust has been imaged in long segments of numerous seismic profiles. Reflections from the crust-mantle boundary are usually imaged as subhorizontal, flat lying, discrete seismic events, roughly parallel to the top of the basement. The lateral continuity of this reflection ranges from a few kilometers ( $3-5 \mathrm{~km}$, e.g., on line 8 , Plate lb) to a nearly continuous feature for tens of kilometers (Plate $1 \mathrm{c}$ ). Away from ridges and seamounts, the thickness of the igneous oceanic crust along all seismic profiles ranges from 2 to $2.5 \mathrm{~s}$ (TWTT). The internal reflectivity of the oceanic basement is restricted to a few faint lower crustal dipping events. In the vicinity of the trench, upper crustal dipping reflections project to the base of clear vertical displacements in the top of the basement and sedimentary cover.

\section{Lower Continental Slope and Trench Axis}

The accretionary prism commonly ranges between 5 and 10 $\mathrm{km}$ in width (Figures 3, 4 and 5). In many lines, the accretionary prism terminates landward against a wedge-shaped unit characterized by high-amplitude reflections along its upper surface and, locally, also along its base (Figures 3,4 and 5). The seismic images of the prism reveal few coherent and continuous reflections. Its internal structure is characterized by some landward dipping reflections cutting through the prism body and a few random, short subhorizontal reflections. The image of the detachment surface that delineates the boundary between the offscraped sediment in the prism and the underthrust sediment is variable across the area but can be observed in some of the seismic records as a subhorizontal or gently dipping reflection of reversed polarity (Figures 4, 5, and 6).

Sediment underthrusting is well displayed along Costa Rica [Crowe and Buffler, 1983, 1985; Shipley et al., 1990, 1992], and beneath the prism, many records even show clear horst and graben structures (Plate Id and Figures 3 and 5). These reflections lose resolution down the subduction zone, but stratification continues beneath the buttress or backstop. In some records, these reflections can be traced from seaward of the trench axis more than $10 \mathrm{~km}$ down the subduction zone, where they gradually lose their seismic character internal geometry (Plates $\mathrm{lb}$ and $\mathrm{lc}$ and Figure 6).

Along the lower slope, the seafloor morphology is locally characteristic of slump masses, and several seismic lines display an intemal structure consistent with such an origin. Topography north of Fisher Seamount (Figure 1) indicates a 5-km seaward advance of the toe of a large slump. In the seismic records a 5km-long high-amplitude reflection with reversed polarity separates a more deformed from a little deformed sedimentary sequence (Plate lc and Figure 4). At the head of the slump the headwall scarp is clearly displayed at the seafloor in the morphology (Figure 1) and seismic sections. In line 15 a diffuse rough seaward dipping surface projects from beneath the scarp and gradually fades. The main internal structure of the foot of the slump is landward dipping reflections of different length, continuity, and reflectivity. In many instances these dipping planes can be projected to the base of seafloor topographic relief (Plate 1c, e.g., line 15 CMPs 11675 and 11380). This huge slump 

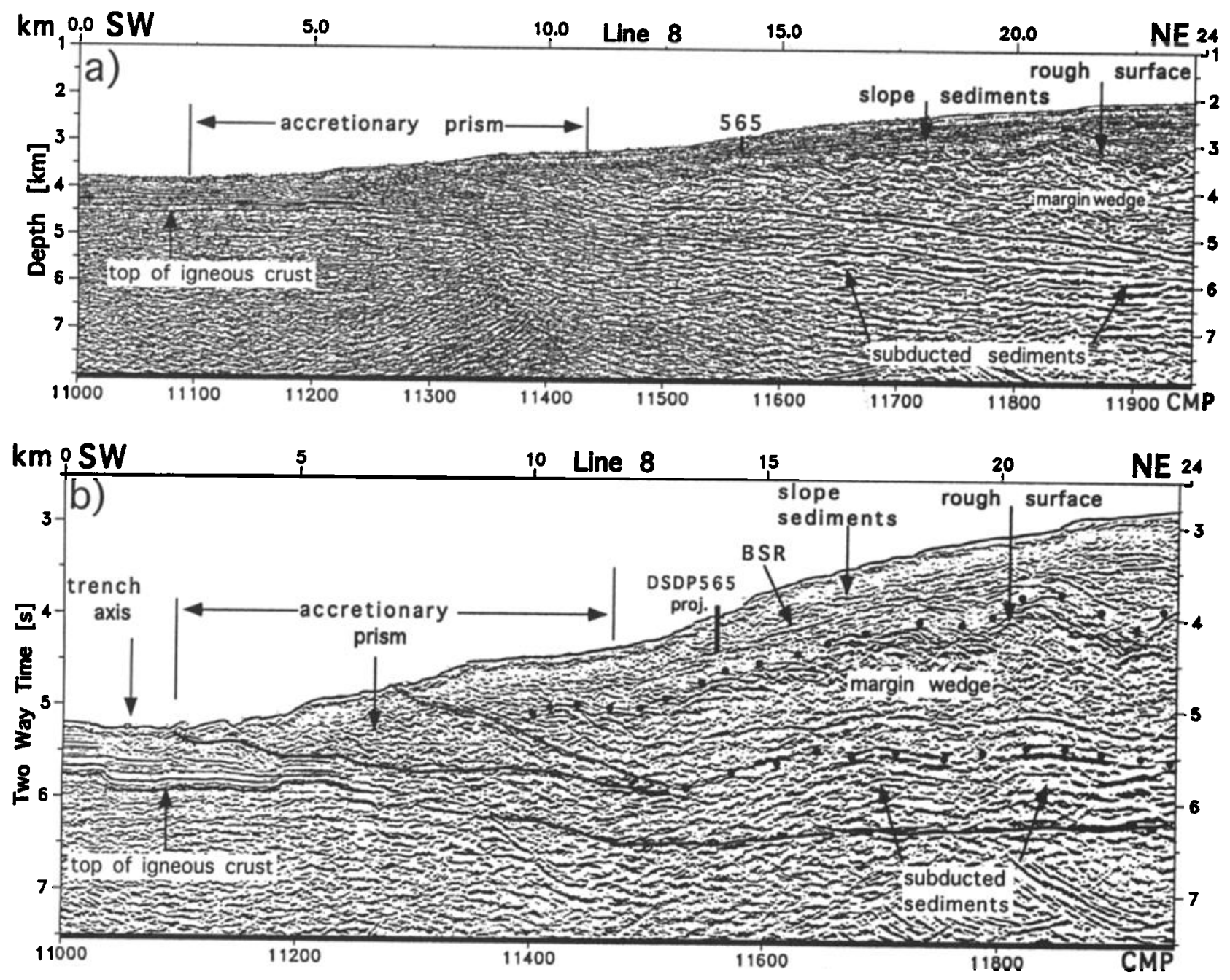

Figure 3. (a) A depth migrated display of line 8 from the trench axis to the middle slope. The rough surface terminates $8 \mathrm{~km}$ from the trench axis at a landward dipping reflection marking the landward boundary of the frontal accretionary prism. (b) A post stack time-migrated display with interpretation is shown for comparison.

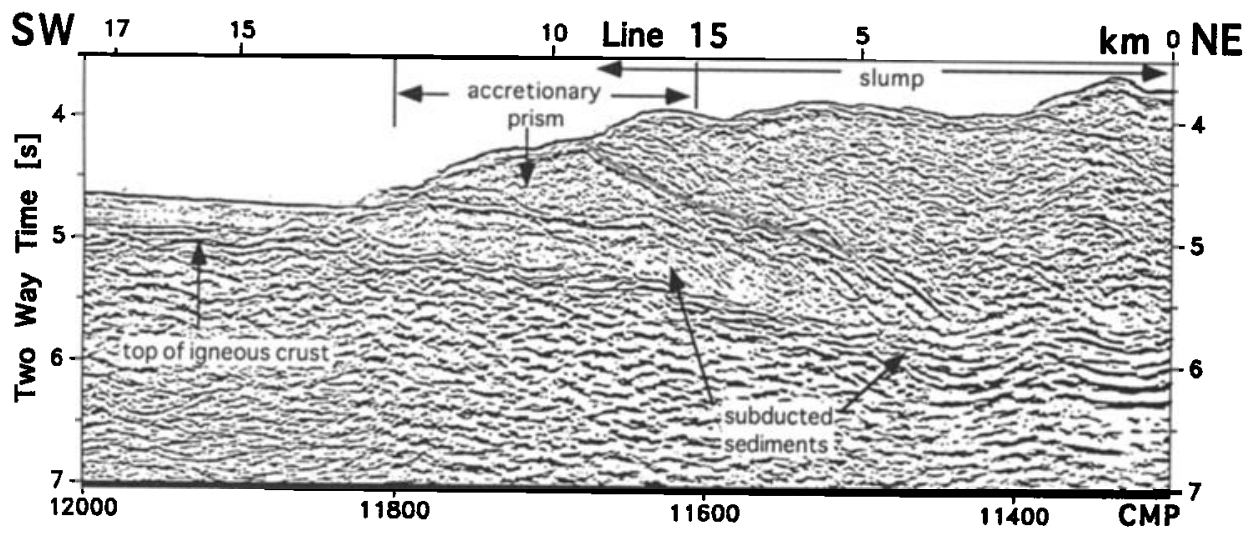

Figure 4. Time-migrated display of line 15 showing the front of a large slump and the frontal prism. The decollement is a strong reflection, $5 \mathrm{~km}$ long, dipping gently landward, that might be the base of the slump. It appears to be slightly shallower than the incoming sedimentary section, and part of the prism material might be added to the subducting sediments. For time-migrated display see Plate 1. 


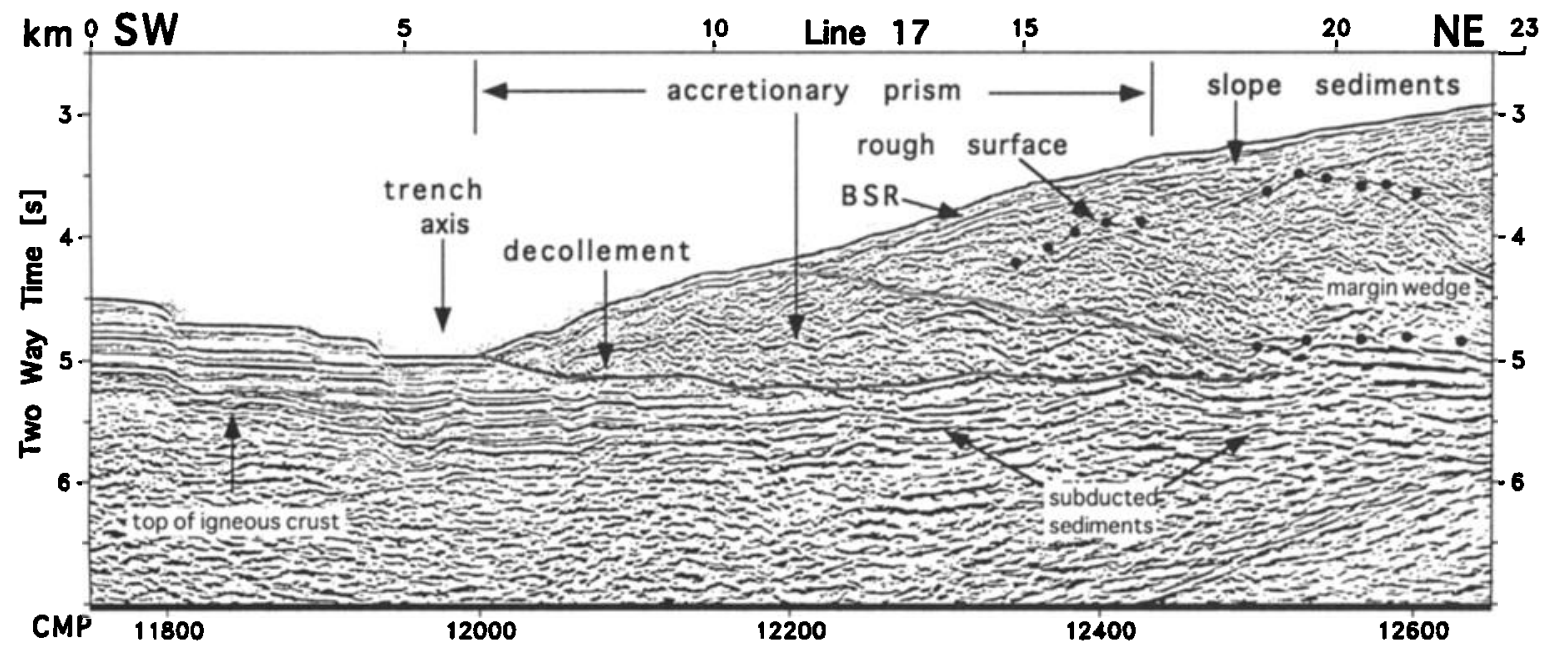

Figure 5. Time-migrated display of line 17 across the trench axis. Efficient sediment subduction is particularly apparent in this record, and only the shallowest trench sediment is scraped off. The decollement appears to be a weak reflection that follows to the topography of the faulted oceanic crust. For location, see Figure 1.

is difficult to resolve with seismic sections alone, and our interpretation is guided principally by the swath-map morphology.

In the middle to upper continental slope, three main seismic units are recognized on the basis of the seismic characteristics (Plates 1b, 1c, and 1d, and Figure 5). The upper is sediments deposited on the slope, the middle is a wedge with little reflectivity, and the lower is underthrust and subducted sediment.

1. The slope sediment extends in depth from the seafloor to a strong irregular reflection called the "rough surface" [Coltrin et al., 1989; Stoffa et al., 1991; Shipley et al., 1992]. The irregular morphology of this surface is most pronounced across the lower and middle slope where it occasionally attains a relief of $500 \mathrm{~m}$ in both dip and strike directions (Figures 3 and 7).
2. The middle unit extends from the rough surface down to a sequence of high-amplitude layered reflections. Its wedge-shaped cross section appears in all seismic sections, and it comprises the bulk of the continental margin. This body was referred to as the Costa Rica terrane by Hinz et al. [1992] and is referred to as the margin wedge in the following.

3. The third unit is a sequence of layered reflections of high amplitude and lateral continuity along the plate boundary. These reflections were sufficiently strong to be imaged with the weak seismic source and early seismic processing techniques first applied to the Costa Rica margin [Buffler, 1982; Crowe and Buffler, 1983].

In the middle slope, the upper sequence of sediments has poor reflection continuity and little internal stratification (Plates $1 \mathrm{c}$ and

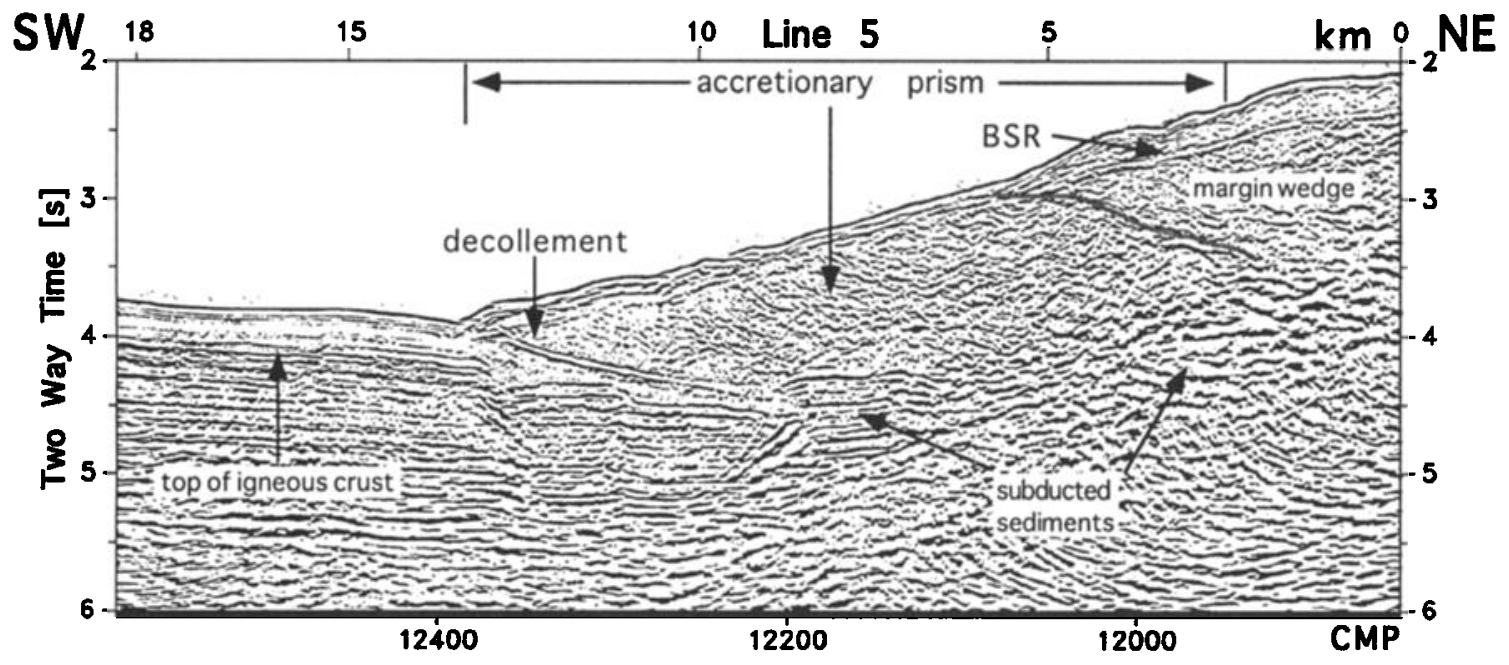

Figure 6. Time-migrated display of line 5 across the trench axis. The bright reflection from the decollement deepens considerably and fades away landward into the oceanic sediment. A BSR rapidly shallows downslope from about $300 \mathrm{~ms}$ to close to the seafloor. 


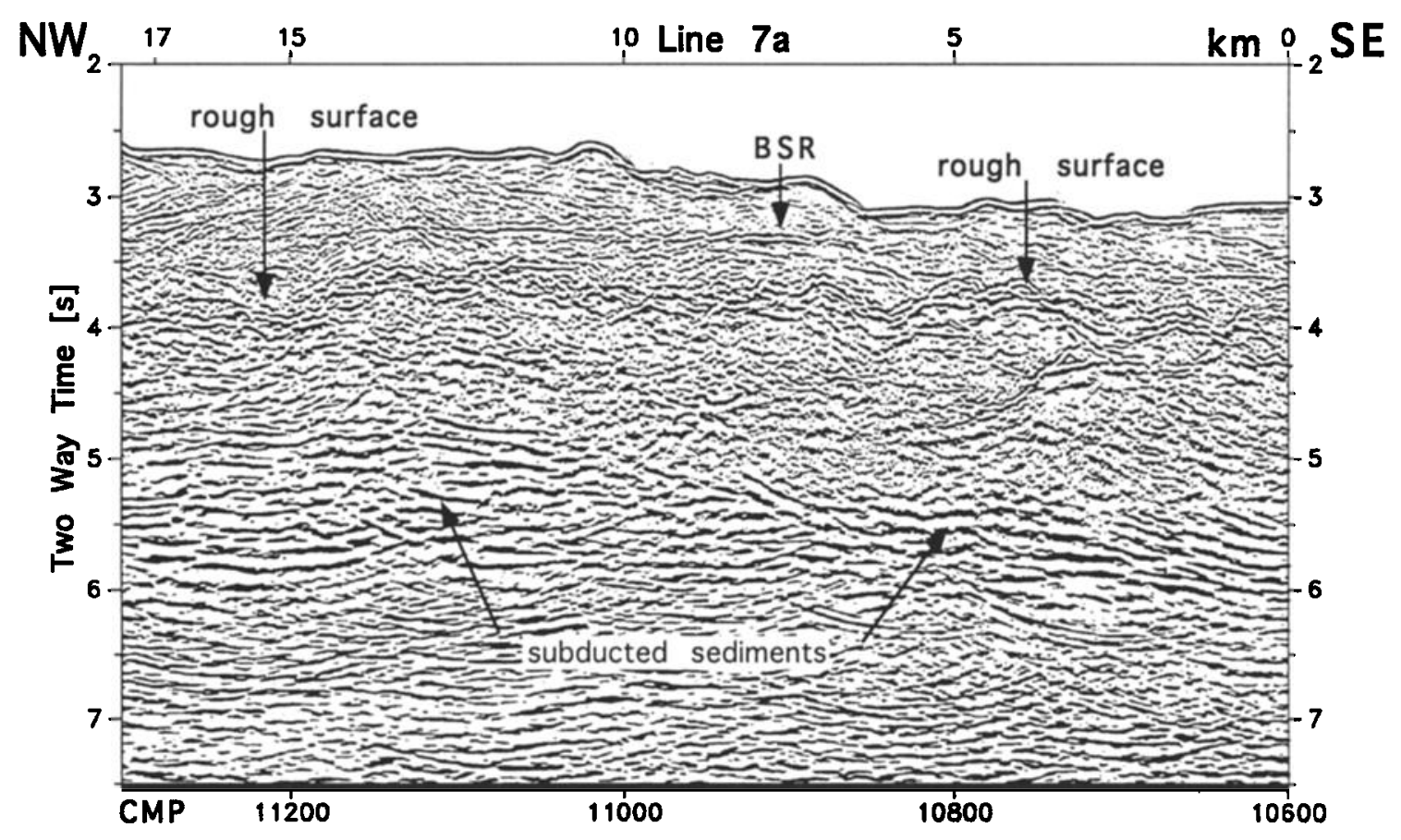

Figure 7. A detailed segment of the time-migrated strike line 7A showing the internal structure of the margin wedge and slope sediments. The rough surface has a relief of up to $500 \mathrm{~ms}$ (about $500 \mathrm{~m}$ ). For location, see Plate 1.

1d). Locally, the stratification is better displayed in strike lines (Plate 1a). Where stratification is visible in the lower part of the section, the strata generally drape over the rough reflective surface of the margin wedge. Locally, strata terminate against a steep feature of the margin wedge. The thickness of the sedimentary apron varies between 0.5 and $2.6 \mathrm{~s}$ (Plate 1a) due to the combined relief of the seafloor and the relief of the margin wedge.

On the upper slope, the sedimentary column generally exhibits better stratification, imaged as subhorizontal, relatively continuous, and locally weakly disturbed reflections (Plate Ic). In some instances the strata lie conformably over a relatively smooth reflective lower boundary.

On most of the seismic sections, clear images of a bottom simulating reflector (BSR) have been obtained in the middle and lower slope. The BSR appears as a distinct reflection NW of the area of Fisher Seamount where its depth below the seafloor gradually decreases from the middle slope $(0.6 \mathrm{~s}-0.5 \mathrm{~s})$ to the lower slope (0.4 s - $0.3 \mathrm{~s}$ ) (Plates $1 \mathrm{a}$ and $\mathrm{lb}$ ). Southeastward, it can locally be observed in the middle slope, although it displays a better continuity in the lower slope.

The margin wedge comprises the greatest volume of material within the continental margin. Its reflective irregular upper surface is coincident with a large velocity increase observed in standard seismic reflection velocity analyses and also in refraction measurements obtained in the area [von Huene and Flueh, 1994; Ye et al., submitted manuscript, 1995]. The change in velocity at the rough surface is from about 2.0 to $2.5 \mathrm{~km} / \mathrm{s}$ in the slope sediment to velocities exceeding $4.5 \mathrm{~km} / \mathrm{s}$ in the wedgeshaped unit. Taking the rough surface as its upper limit, the seawardmost extension of the wedge commonly extends to within 8 to $10 \mathrm{~km}$ of the trench axis.
This body has a variable structure, the main features being landward dipping reflections that in most cases do not displace the rough surface and low-amplitude reflections parallel to the upper and lower surfaces. Beneath the upper slope and shelf, rough surface relief diminishes and merges into a smooth surface (Plates $1 \mathrm{c}$ and $1 \mathrm{~d}$ ). Here internal reflections are horizontal or very gently dipping. Strike lines also show southeast and northwest dipping reflections (Plates $1 \mathrm{a}$ and Figure 7). The internal structure of the margin wedge provides few constraints on its origin. In the part studied by Shipley et al. [1992], the thin forward part of the wedge has an accretionary structure. Under the upper shelf and slope in their study area, the structure includes larger coherent units between major faults.

Beneath the margin wedge is a sequence of parallel, highamplitude reflections. The reflections are locally continuous in dip and strike lines and are either continuous for $4-6 \mathrm{~km}$ or in groups of shorter reflections. The thickness of the sequence ranges from $300-400 \mathrm{~ms}$ up to $1000 \mathrm{~ms}$ and is recognizable beneath the slope and shelf. The composite appearance from several records is a continuous reflective sequence between the upper and lower plates beginning at the trench axis and continuing down the subduction zone.

The information from lines $4,13,17 \mathrm{~A}$ (not shown), and 5 (Plate 1d) shows that the three main units observed below the slope area are also present beneath the continental shelf. However, there are two noticeable differences:

1. Sediment above the margin wedge has a more uniform thickness, better stratification, and good continuity. On lines 17A and 13, normal faulted and tilted strata are clearly imaged beneath the continental shelf. In contrast, line 5 shows indications of local compression in the seaward end of the shelf where strata are gently uplifted and truncated at the seafloor. 
2. The surface separating the sedimentary sequence from the wedge is no longer rough but relatively smooth (Plate 1d). In addition, this surface exhibits strong variations in reflectivity from profile to profile.

\section{Discussion}

Despite the variability of the subducting plate, the corresponding margin morphology, the diverse shelf structure, and the variability in the coastline, the basic upper plate structure consists of the margin wedge covered by slope sediment, underthrust by trench sediment, and fronted by an Quatemary to upper Miocene(?) accretionary prism. This singular structure was observed in seismic lines along the entire Costa Rican margin from the Cocos Ridge to the end of the Nicoya Peninsula. Critical to an understanding of the tectonic history and the tectonic mechanisms that have shaped this margin is a knowledge of the nature and origin of the margin wedge. Neither of the two hypotheses proposed can be excluded from consideration notwithstanding some of the best geophysical data along any convergent margin. As stated previously, the first hypothesis suggests that the margin wedge is mainly a seaward extension of the Jurassic through Cretaceous oceanic rocks that crop out onshore. The second hypothesis implies that the margin wedge is consolidated sediment of an Eocene to Quaternary accretionary complex of oceanic offscraped and underplated sediments. The two end-member histories of tectonic processes inherent in these hypotheses are a changing versus a steady state plate tectonic history since Eocene time. In Eocene time, the Nicoya Peninsula was uplifted from abyssal to neritic depths. One major change recorded in the young history of Central America is the introduction of Cocos Ridge to the subduction zone between 1 Ma [Lonsdale and Klitgord, 1978] and 3.6 Ma [Collins et al., 1995]

\section{Origin of the Margin Wedge}

The wedge has not been knowingly sampled in the marine environment to test its igneous or sedimentary affinities. Thus current interpretations must rely on geophysical observations and similarities with neighboring stratigraphic sections. The evidence favoring a steady state accretionary origin have recently been thoughtfully presented [Shipley et al., 1992]. Our emphasis is on the non-steady state accretionary aspects that have not been discussed or fully appreciated in recent publications.

The following observations are more easily explained with a varied rather than a steady state accretionary history:

1. Beneath the middle and upper slope, the margin wedge displays few landward dipping reflections typical of accretionary masses despite the more powerful seismic source used in this study (3124 versus 1800 inch $^{3}$ (29.5 L) [Stoffa et al., 1991]). The margin wedge consists of high-velocity rock whose internal structure is poorly reflective. Locally, landward dipping reflections extend partially across it, but, more commonly, the structure consists of low-amplitude reflections lacking extensive continuity such as those from out-of-sequence thrusts. These are principally subparallel to the upper or lower boundaries of the body.

2. The ubiquitous rough surface demonstrates with its high reflectivity and large velocity contrast a significant break in geology over the entire area. Shipley and his colleagues [Shipley et al., 1992] showed that the rough surface has no clear lineation in the 3-D area and from examination of strike lines that seems to be typical across the whole margin. Canyons or other erosional features are not strongly developed in the surface. The rough surface reflectivity continues under the shelf basin on sections shown here.

3. On line 5 (Plate 1d), the continuation of the rough surface loses its irregular character and becomes a smooth reflection that forms the floor of a forearc basin. The basin is filled with regularly stratified sediment $2 \mathrm{~km}$ and more thick. A seismic stratigraphic study of an industrial multichannel seismic reflection grid over the continental shelf between the Nicoya and Osa peninsulas correlates the smooth equivalent of the rough surface reflection with the top of the Nicoya Complex [Barboza and Zucchi, 1994].

4. A clear stratal onlap indicating a time transgression of the surface down slope is absent. A constant accretionary outbuilding since Eocene time should be accompanied by some clear seaward downlap of slope sediment reflections across newly accreted areas.

5. Locally, the basal sediment blanket has been displaced up to a few hundred meters along contractile and extensional faults. In general, the sediment blanket is not highly discordant, but almost as often the strata abut features in the rugged surface relief. This pattern of sedimentation can be attributed to slope deposition on a mildly irregular surface that was later disrupted.

6. Lastly, a discontinuity in structure or velocity representing a contact between the igneous rock exposed along the shore and an accretionary prism is absent from any reflection and refraction seismic data across the shelf and upper slope (Ye et al., submitted manuscript, 1995).

The age of the rough surface of the margin wedge should also help to understand its origin. If the margin were configured during Eocene time with lesser modification afterward, then older Neogene or pre-Neogene sediment would have been deposited on the rough surface. Some information regarding the age of the rough surface can be inferred from the stratigraphy in DSDP 565 (DSDP Leg 84) in comparison with the section onshore and that known from drill holes in the same environment. Drilling during DSDP leg 84 was terminated at Site 565 due to recovery of gas hydrate, and about $300 \mathrm{~m}$ of sediment above the rough surface was left unsampled. Despite lack of a definite age, an estimate indicates a minimum Miocene age of the surface beneath the lower slope (Figure 8). The base of the upper Pliocene (3.5 Ma) was sampled at $280 \mathrm{~m}$, and indications of late Miocene nannofossils and benthic foraminifers were noted to $328 \mathrm{~m}$ [Filewicz, 1985; McDougall, 1985]. Projecting the rate of sedimentation measured in the Pliocene from these depths to the base of the sediment section (estimated at $600 \mathrm{~m}$ by Shipley et al. [1992]) gives a minimum age at the rough surface between 6.7 and 8.2 Ma. Comparing the Costa Rican section at Site 565 with sites in the same environment off Guatemala shows a much thicker drilled Pliocene at the Costa Rican site (Figure 8). The ODP sites on the lower slope of the Peruvian margin (allowing for the ponded Pleistocene sediment at Site 688) also have a thinner Pliocene unit in a slope section of similar thickness to Costa Rica (Figure 8). The drilled stratigraphic sequence at the Guatemalan and Peruvian lower slope contains strata of similar age and provenance to those exposed on the Nicoya Peninsula. A consolidated sandy sedimentary rock which resembles some of the Eocene lithologies was dredged from the midslope area near 


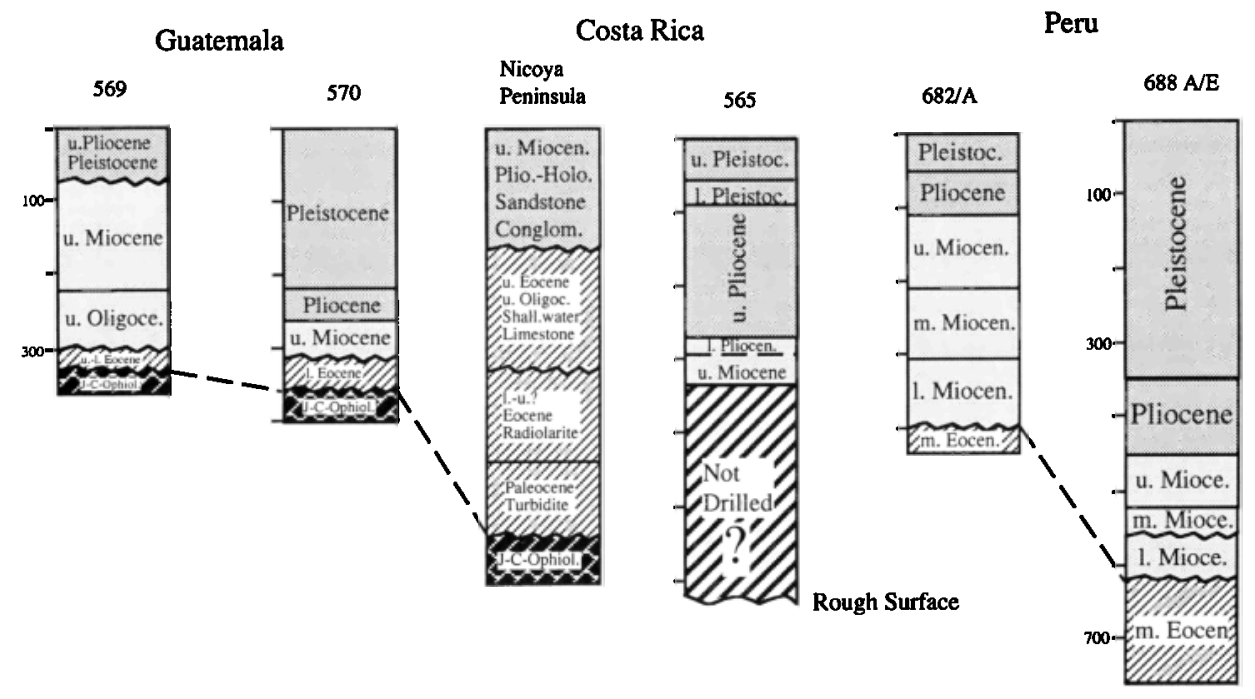

Figure 8. Comparison of DSDP stratigraphy from Guatemala [von Huene et al., 1985] and Ocean Drilling Program (ODP) data from Peru [Suess et al., 1988] with DSDP hole 565 and the onshore stratigraphic sequence [after Winsemann, 1994; Sprechmann et al., 1994]. Projecting the upper Pliocene rate of sedimentation at site 565 to the base of the section gives a minimum age of 6.7 Ma. J-C Ophiol. stands for Jurassic-Cretaceous ophiolite.

Cabo Blanco [von Huene et al., 1995]. Thus it is likely that the Eocene section exposed at the coast extends a considerable distance offshore perhaps to the lower slope as along other parts of the central and south America margin.

An estimated age of the rough surface near DSDP hole 565 indicates the maximum accretion that might have taken place in that area of the slope. Taking $90 \mathrm{~mm} / \mathrm{yr}$ as convergence rate and $425 \mathrm{~m}$ as sedimentary thickness at the trench yields a volume of incoming material of $285 \mathrm{~km}^{3}$ per $\mathrm{km}$ of trench for the past 7.45 Ma (average of 6.7 to $8.2 \mathrm{Ma}$ ). Projecting DSDP site 565 onto line 8 , a volume balance on the material seaward of the drill site and beneath the slope sediments, indicates that about $5 \%$ of the incoming material is accreted. These calculations, despite their loose constraints, suggest slow accretion and highly efficient sediment subduction.

To summarize, the above observations and the interpretation of our seismic reflection data fit better with an origin of the margin wedge as an equivalent of the ophiolite exposure on the Nicoya Peninsula. However, without direct sampling of the margin wedge, none of the current hypotheses can be disregarded.

\section{The Response of the Margin to the Subduction of Topographic Relief}

The surficial deformation of the upper plate linked to the subduction of the Cocos Ridge and smaller-scale rough topography present in a segment of the converging oceanic plate has been studied by von Huene et al. [1995] (Figure 1). The bathymetric map shows numerous seamounts and volcanic ridges across the subducting slab. On the slope, it also shows the morphological features caused by the subduction of seamounts as linear furrows, uplifted dome shaped areas, and slumps of different dimensions. These morphological features are interpreted as the trail of seamounts at different stages of subduction [von Huene et al., 1995]. Lines 5 and 15 (Plates 1c and 1d) are two examples that display the dramatic changes occurring in the internal structure of the upper plate crust in areas where rough topography is subducted. Line 15 was shot across a large slump revealed in the bathymetric map that covers approximately a 42 by $22 \mathrm{~km}$ area of the trench. The seismic line shows the effects in the structure of the margin from the subduction of a seamount in line with the trend of Fisher Seamount. The seismic image indicates detachment along the head of the slide (CMPs 10900 to 11100 , Plate Ic) and overthrusting at the foot. The failure involves slope material that was about $1 \mathrm{~km}$ deep. The volume of material of the slump presently covering the trench, constrained with seismic lines 21 (not shown) and 15, is about $925 \mathrm{~km}^{3}$. However, the volume of material involved in the original slump was probably as much as $1320 \mathrm{~km}^{3}$ and has partially been subducted behind the gap left by the subducting seamount (Figure 1). The volume of the slumped material is comparable with a slope slide observed along the Peru Trench [von Huene et al., 1989]. A calculation of the tsunami which would be generated by that slide if it failed catastrophically indicates a 50-m wave height along the adjacent coast. If the slide off Costa Rica detached and slumped catastrophically, a similar local tsunami, along the adjacent Nicoya Peninsula, was generated.

\section{Conclusions}

A singular structural configuration was observed in seismic lines along the entire Costa Rican margin from the Osa Peninsula to the middle of the Nicoya Peninsula. The basic structure consists of a margin wedge covered by slope sediment, underthrust by trench sediment, and fronted by a small accretionary prism. This is the basic structure produced by the convergence of normal Cocos Plate against Costa Rica. The basic structure was modified during subduction of ocean crust associated with the Cocos Ridge and a swath of seamounts along the north flank of the ridge. Opposite the ridge crest is Osa 

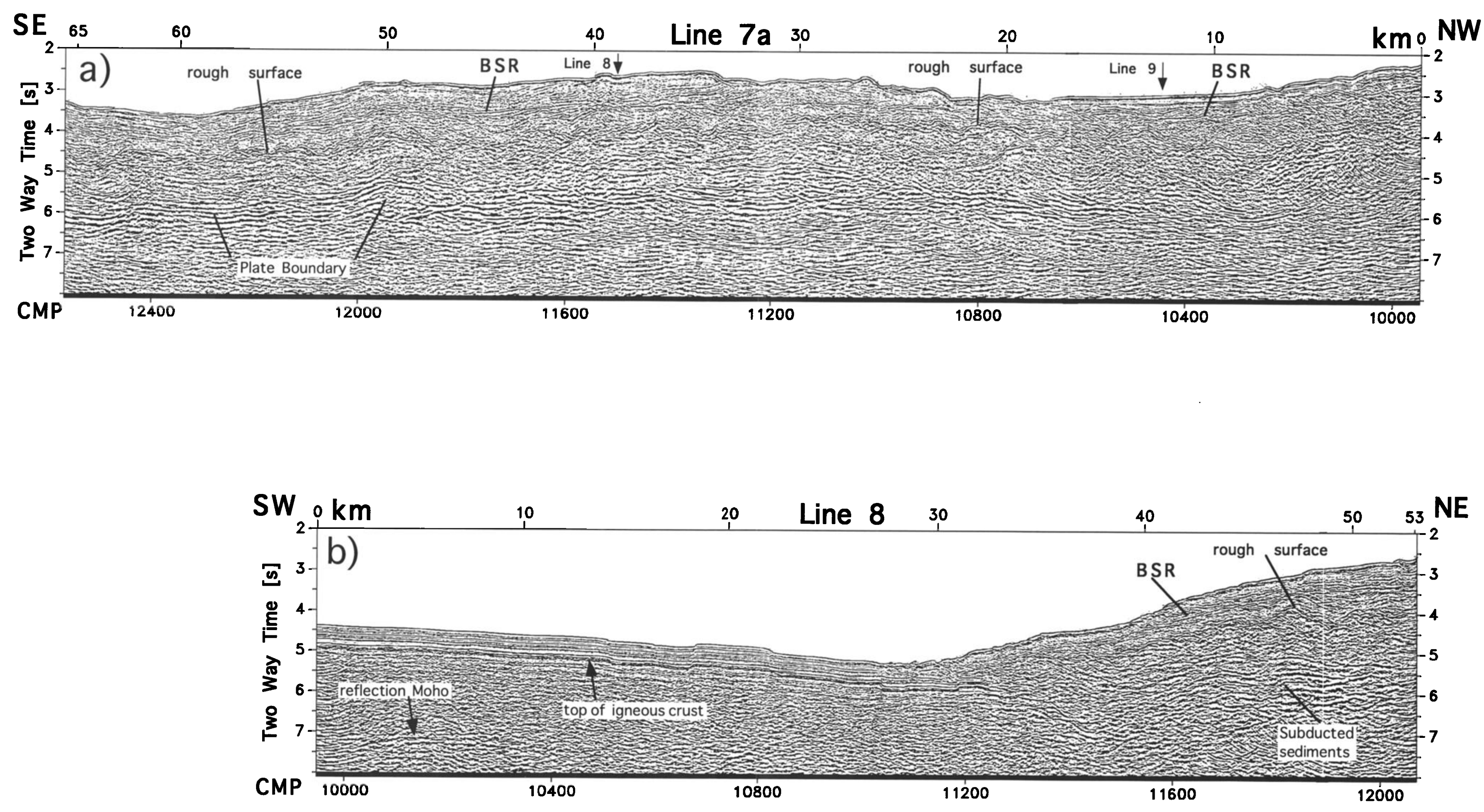

Plate 1. Four time-migrated seismic-reflection lines showing the strong diversity of the tectonic structures along the Costa Rica margin. Along the horizontal axis 400 common midpoints (CMPs) equals $10 \mathrm{~km}$. For location, see Figure 1. (a) Line 6 displays he conthity of features along stike. The reflective sequence along the plate the entire profile. The subhorizontal and dipping feanures berween them could locally be from out of the plong the section A relatively continuous BSR reflection cuts toun the layering at about 500-600 ms benth the seafloor. (b) Line 8 shows a section across the trench. The combination of lines $7 \mathrm{~A}$ and 8 shows the the rough surface is irregular in two dimensions. Immediately seaward of the trench axis, normal faults cut the oceanic crust. (c) Line 15 contains a large slump (see Figure 1 for location). The rough surface is smoother beneath the upper slope. The thickness of the oceanic crust near the Fisher Seamount lineament (Figure 1) is about $3 \mathbf{~ s}$, slightly thicker than normal. (d) Line 5 exhibits a transition from the rough surface beneath the slope to a smoother reflection benelth the conthental shelf. The sedinents above this surface appear uplifed along the shelf edge. The basal shelf sediment is gently unconformable with the topography of the smooth surface. The margin wedge displays numerous reflections beneath the continental shelf. 

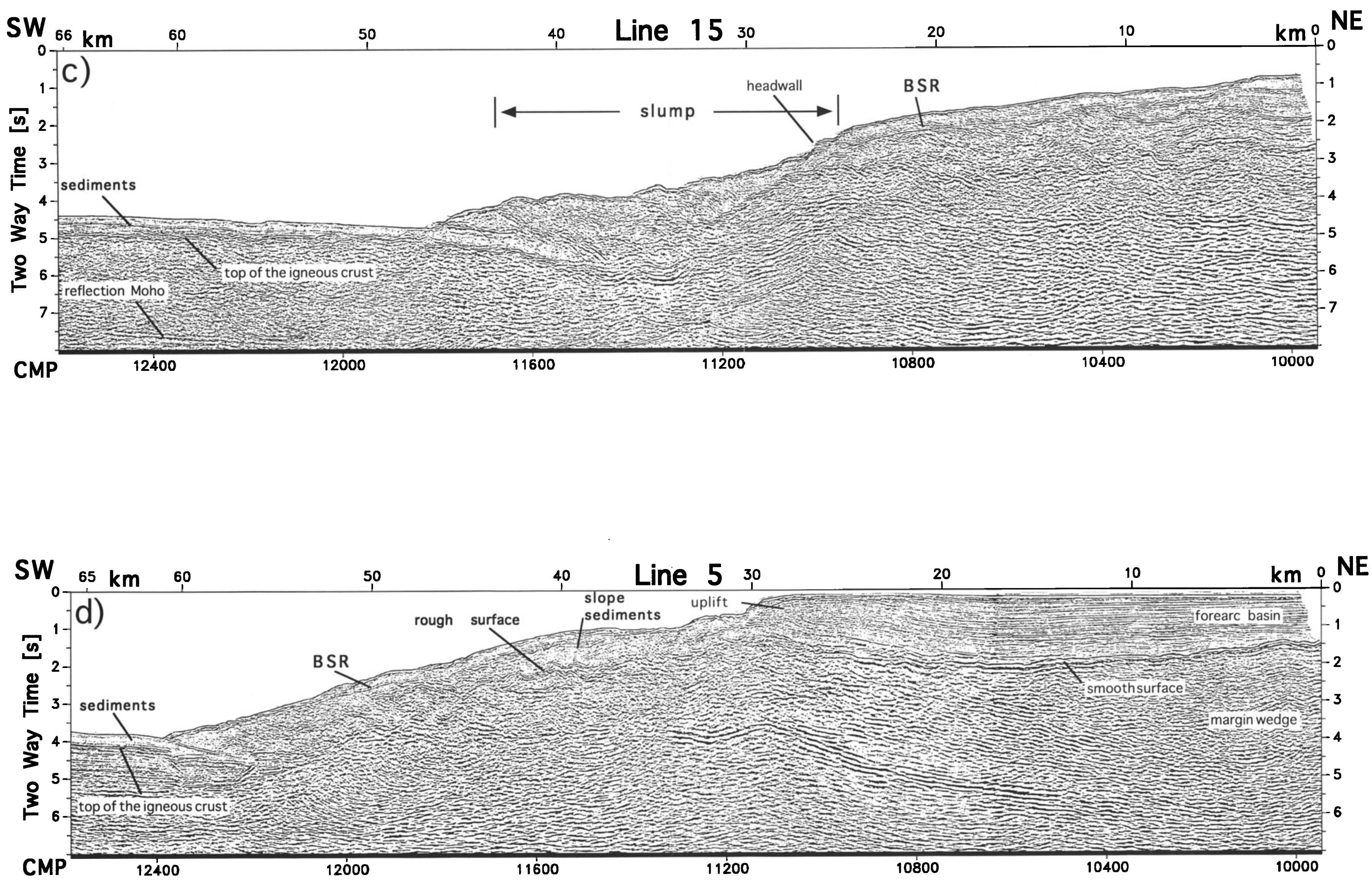

Plate 1. (continued) 
Peninsula, which has undergone broad uplift. Opposite the seamounts, the continental slope has retreated, whereas opposite the northwest ridge flank, the shelf attains maximum width.

Despite slope retreat, accretion has renewed the prism to the width where the margin is not currently impacted by subducting seamounts. Only along the row of seamounts projecting from Fisher Seamount, may subduction erosion have indented the margin wedge as mapped by Hinz et al. [1992]. Thus a basic structure is maintained, perhaps showing the enduring nature of the margin wedge, whereas the accretionary prism is more ephemeral.

The origin of the margin wedge and especially its rough upper surface is not evident from current data. The rough surface is characterized by a marked absence of tectonic grain in 3-D and 2$D$ data; it has no obvious erosional channel system. Local images of the disconformity between sedimentary bedding and the rough surface indicate that much of its topography existed prior to slope sedimentation. The high velocities of the margin wedge that contrast with the overlying slope sediment suggest initial construction of the consolidated rock body and slope sedimentation after a geologic break. Later deformation modified the surface and the lower beds of the slope sediment sequence. Beneath the shelf, the smooth counterpart to the rough surface and the shallow water Eocene-Quaternary sedimentation on the Nicoya Peninsula limit the extent of the rough topography to the continental slope. Roughness is greater along the deeper half of the margin than at the top. At the seaward edge of the shelf the development of the margin wedge occurred in Paleogene time (Eocene?) when the shelf basin formed and the Nicoya area was uplifted from deep water [Seyfried et al., 1991; Winsemann, 1994]. Although the slope sediment thins seaward, there is little evidence that can be used to estimate a progressively younger age in a seaward direction.

The foot of the slope is formed by a currently accreting prism which passes landward from a series of thrust structures into the rough surface. Velocities below the rough surface increase steadily to the midslope where they reach values common in the Nicoya complex. This can be interpreted as a growing margin [cf. Shipley et al., 1992] with essentially continuous very slow accretion of trench sediment that consolidates across the lower slope to attain velocities above $4 \mathrm{~km} / \mathrm{s}$ and is therefore not physically distinct from the Nicoya complex. Alternately, it is permissible to interpret the velocities and structures as formed by the apex of an eroded margin wedge against which a small prism has accreted. The Nicoya complex could extend to the middle slope and transition through a tectonically disrupted serpentinized zone to the sedimentary accretionary prism. This is our favored interpretation; however, each interpretation has merits and problems that preclude an exclusive choice of alternate interpretation until further constraints are found.

Acknowledgments. We are grateful to the German Ministry for Research and Technology (BMFT) for their support of this study under grants 03R422C/03G0081C and to Captain Kull and the crew of the Sonne. Reviews by N. Bangs, A. Mascle, H. Seyfried, and G. Alvarado, an anonymous reviewer, and comments of the Editor greatly improved our original submitted manuscript. We acknowledge the assistance of the Instituto Costarricense de Electricidad (ICE) and are indebted to C. Germann, Geman Embassy, for support. C. R. Ranero was supported by the European Union under the Human Capital and Mobility program. Figure 1 is contoured with GMT public software [Wessel and Smith. 1991].

\section{References}

Ambos, E.L., and D.M. Hussong, Structure at the toe of the subduction complex: Middle America Trench off shore Guatemala, Deep Sea Drilling Project Leg 84, edited by R. von Huene et al., Initial Rep. Deep Sea Drill. Proj., 84, 861-878, 1985.

Barboza, G., and H. Zucchi, Sismoestratigrafia de algunas cuencas en el antearco del sector central de Costa Rica, Profil, 7, 161-169, 1994.

Buffler, R.T., Geologic structure of the forearc region off the west coast of Costa Rica in the vicinity of the Nicoya Peninsula-results of a multifold seismic reflection survey, Tech. Bull., UT-IG-Tr-39, 56 pp., Univ. of Tex. at Austin, 1982.

Collins, L.S., A.G. Coates, J.B.C. Jackson, and J.A. Obando, Timing and rates of emergence of the Limon and Bocas del Toro Basins: Caribbean effects of Cocos Ridge subduction, in Geologic and Tectonic Development of the Caribbean Plate Boundary in Southern Central America, edited by P. Mann, Spec. Pap., Geol. Soc. Am. 295, 263-289, 1995.

Coltrin, G., M. Backus, T.H. Shipley, and M. Cloos, Seismic reflection imaging problems resulting from a rough surface at the top of the accretionary prism at convergent margins, J. Geophys. Res., 94(B12), 17,48517,496, 1989.

Crowe, J.C., and R.T. Buffler, Regional seismic reflection profiles across the Middle America Trench and convergent margin of Costa Rica, in Studies in Geology Series, vol. 153, edited by A.W. Bally, pp. 4.2-1473.4.2-162, Am. Ass. of Pet. Geol., Tulsa, Okla., 1983.

Crowe, J.C., and R.T. Buffler, Multichannel seismic records across the Middle America Trench and Costa Rica-Nicaragua convergent margin, NCY-7 and NCI-1, in Middle America Trench off western Central America, Ocean Drilling Program, Regional Data Synthesis Series, Atlas 7, edited by J.W. Ladd and R.T. Buffler, 6-11 pp., Mar. Sci. Intl., Woods Hole, Mass., 1985.

Filewicz, M.V., Calcareous nannofossil biostratigraphy of the Middle America Trench and slope, Deep Sea Drilling Project Leg 84 , edited by $R$. von Huene, et al., Initial Rep., Deep Sea Drill. Proj., 84, 339362,1985 .

Fisher, R.L., Middle America Trench: Topography and structure, Geol. Soc. Am. Bull., 72, 703-720, 1961.
Flueh, E.R., S. Ye, A. Stavenhagen, G. Leandro, and J. Bialas, Pacomar, Sonne 76, Compilation of seismic data, data report, GEOMAR, Res. Cent, for Mar. Geosci. Kiel, Germany, 1992.

Hey, R., Tectonic evolution of the Cocos-Nazca spreading center, Geol. Soc. Am. Bull., 88, 1404-1420, 1977.

Hinz, K., and Scientific Crew, Geoscientific investigation off Costa Rica, Pacomar II, Archiv-Nr. 110.148, Tagebuch-Nr. 12.212/92, internal report, Bundesanst. fuer Geowissenschaften und Rohstoffe, Hannover, Germany, 1992.

Lonsdale, P., and K.D. Klitgord, Structure and tectonic history of the eastem Panama Basin, Geol. Soc. Am. Bull., 89, 981-999, 1978.

McDougall, K., Miocene to Pleistocene benthic foraminifers and paleoceanography of the Middle America Slope, Deep Sea Drilling Project Leg 84, edited by R. von Huene et al., Initial Rep., Deep Sea Drill. Proj., 84, 363-418, 1985.

McIntosh, K., E. Silver, and T. Shipley, Evidence and mechanisms for forearc extension at the accretionary Costa Rica convergent margin, Tectonics, 12 (6), 13801392, 1993. 
Moore, G.F., and T.H. Shipley, Behavior of the decollement at the toe of the Middle America Trench, Geol. Rundsch., 77(1), 275-284, 1988.

Mutter, C.Z., and J.C. Mutter, Variations in thickness of layer 3 dominate oceanic crustal structure, Earth Planet. Sci. Lett., 117, 295$317,1993$.

Seely, D.R., P.R. Vail, and G.G. Walton, Trench slope model, in Geology of Continental Margins, edited by C.A. Burk and C.L. Drake, Pp. 261-283, SpringerVerlag, New York, 1974.

Seyfried, H., H. Amann, A. Astorga, C. Calvo, W. Kolb, H. Schmidt, and J. Winsemann, Anatomy of an evolving Island Arc: Tectonic and eustatic control in the south Central American forearc area, in Sea-Level Changes at Active Plate Margins: Processes and Products, edited by D.I.M. MacDonald, Spec. Publ. Int. Assoc. Sedimentol., 12, 217-240, 1991.

Shipley, T.H., and G.F. Moore, Sediment accretion, subduction and dewatering at the base of slope off Costa Rica: A seismic reflection view of the decollement, $J$. Geophys. Res., 91(B2), 2019-2028, 1986.

Shipley, T.H., P.L. Stoffa, and D.F. Dean, Underthrust sediments, fluid migration paths, and mud volcanoes associated with the accretionary wedge off Costa Rica: Middle America Trench, J. Geophys. Res., 95(B6), 8743-8752, 1990.

Shipley, T.H., K.D. McIntosh, E.A. Silver, and P.L. Stoffa, Three-dimensional seismic imaging of the Costa Rica accretionary prism: Structural diversity in a small volume of the lower slope, J. Geophys. Res., 97(B4), 4439-4459, 1992.

Sprechmann, P., A. Astorga, C. Calvo, and A. Femandez, Stratigraphic chart of the sedimentary basins of Costa Rica, Central America, Profil, 7, 427-433, 1994.

Stoffa, P.L., T.H. Shipley, D.F. Dean, W.K. Kessinger, R. Elde, E. Silver, D. Reed, and A. Aguilar, Three-dimensional seismic imaging of the Costa Rica accretionary wedge: Field program and migration examples, J. Geophys. Res., 96(B13), 2169321712, 1991.

Suess, E., et al., Procedings of the Ocean Drilling Program, Initial Reports, vol. 112, Ocean Drill. Program, College Station, Tex., 1988.

U.S. Geological Survey, Miocene resource assessment of the Republic of Costa Rica, U.S. Geol. Surv. Misc. Invest. Ser. Map IJ865, 1987.

von Huene, R., A large Tsunamogenic landslide and debris flow along the Peru Trench, $J$. Geophys. Res., 94(B2), 1703-1714, 1989.

von Huene, R., and E.R. Flueh, A review of marine geophysical studies along the Middle American Trench off Costa Rica and the problematic seaward terminus of continental crust, Profil, 7, 143-159, 1994.

von Huene, R., J. Bourgois, J. Miller, and G. Pautot, A large tsunamogenic landslide and debris flow along the Peru Trench, $J$. Geophys. Res., 94(B2), 1703-1714, 1989.

von Huene. R. et al., Site 565, Initial Rep. Deep Sea Drill. Proj., 84, 21-77, 1985.

von Huene, R. et al., Morphotectonics of the Pacific convergent margin of Costa Rica, in
Geologic and Tectonic Development of the Caribbean Plate Boundary in Southern Central America, edited by P. Mann, Spec. Pap., Geol. Soc. Am., 295, 291 -308, 1995.

Wessel, P., and W.H.F. Smith, Free software helps map and display data, EOS Trans. AGU 72, 441, 445-446, 1991.

White, R.S., D. McKenzie, and R.K. O'Nions, Oceanic crustal thickness from seismic measurements and rare earth element inversion, J. Geophys. Res., 97, (B13), 19,683-19,715, 1992.

Winsemann, J., Origin and tectonic history of the westem Caribbean region, Profil, 7, 1-5, 1994.

H.O. Bargeloh, M. Block, J. Fritsch, K. Hinz, P. Kewitsch, H. Meyer, and B. Schreckenberger, Bundesanstalt für Geowissenschaften and Rohstoffe, Stilleweg 2, 30655, Hannover, Germany

E. Flueh (e-mail: eflueh@geomar.de), D. Klaeschen (e-mail: dklaeschen@geomar.de), J. Leinbach, C.R. Ranero (e-mail: cranero@geomar.de), O. Ruoff, (e-mail: oruoff@geomar.de) and R.von Huene (e-mail: thuene@geomar.de), GEOMAR, Research Center for Marine Geosciences, Wischhofstr. 13, 24148 Kiel, Germany

J. Mrazek, Universität Greifswald, Fachrichtung Geowissenschaften Jahnstr. 17a, 0-2200 Greifswald, Germany

(Received January 11, 1995;

revised July 5, 1995;

accepted July 10, 1995.) 